\title{
Evaluation of STD/HIV/AIDS peer-education and danger: a local perspective
}

\author{
Avaliação de educação das DST/HIV/aids pelos pares e perigo: \\ uma perspectiva local
}

Hélène Laperrière ${ }^{1}$

${ }^{1}$ School of N ursing, Faculty of $\mathrm{H}$ ealth Sciences, University of Ottawa. 451, Smyth Road. K1H 8M 5 Ottawa ON Canada. hlaperri@uottawa.ca
Abstract An evaluation of peer-education projects with sex workers, men who have sex with men and marginalized adolescents, was introduced in a remote region of Brazil. The context of varied limits of predictability made it difficult to conduct inquiry. To go beyond available epidemiological surveys and questionnaires on sexual behavior, a self-evaluation aimed at increasing pragmatic knowledge about prevention in a challenging socio-political context. During five-months, a participatory-action research explored participant observation; individual and collective exchanges with users, peer-educators, coordinators, administrators, politicians and regional health professionals. Collective understanding of peer-education in prostitution zones underlines the reality of unforeseen social repercussions and confluence/ divergence of multiple actors' perspectives. It identifies meaningful dimensions at a community-level, such as the collective history and dangerous working conditions. N urses face complex struggles and negotiations over multipleactorsin their practice. This study suggests that nurses have a role to play in the conceptualization of participatory evaluation. It also underlines the threats to their physical and social safety, which they might sharewith peer-educators.

Key words Peer-education, Participatory evaluation, STD/HIV/AIDS, Politics, Public H ealth Nursing
Resumo U ma avaliação dos projetos de educação por pares com trabalhadores do sexo, homens que fazem sexo com homens eadolescentes marginalizadosfoi implantada numa região do interior do Brasil. Os diversos limites postos à previsibilidadetornaram difícil conduzir a investigação. Indo além das pesquisas epidemiológicas equestionários evolutivos sobreos comportamentos sexuais, esta autoavaliação enfatiza o desenvolvimento de conhecimento pragmático sobre prevenção em um contexto sociopolítico desafiante. Durante cinco meses, uma pesquisa-ação explorou observação participante, entrevistas individuais e coletivas junto com usuários, pares educadores, coordenadores, administradores, políticos e profissionais da saúde. A compreensão coletiva da educação por pares em áreas deprostituição sublinha a realidade derepercussões sociais imprevistas e a confluência/divergência das perspectivas de diversos atores locais. A pesquisa identifica dimensões coletivas significativas como a historia coletiva e as condições de trabalho perigosas. As enfermeiras enfrentam complexas lutas e negociações com múltiplos atores no âmbito da sua prática. Este estudo ressalta o papel importante delas na conceitualização de avaliação participativa. 0 estudo também destaca as ameaças para a segurança física esocial queas enfermeiras compartilham com os pares educadores.

Palavras-chave Educação por pares, avaliação participativa, DST /HIV/AIDS, Política, Enfermagem em saúde coletiva 
The background of a Brazilian HIV/AIDS context: multiple actors and unpredictability

Theincrease of population displacements in Latin America has led to a rupture in the social fabric. The displacement of working-ageindividuals to suburban peripheral regions resulted in the emergence of ghettoes rife with poverty, unemployment, alcoholism and prostitution and led to the creation of vulnerability to infections, HIV in particular ${ }^{1,2}$. Viewed as being highly at risk due to their behavior and living conditions, these populations have been targeted as themain challenge for HIV/AIDS prevention in the new millennium in the Third Brazilian Congress on STDs/ AIDS prevention (1999). Brazil accounts for more than onethird of theestimated 1.8 million people living with HIV in Latin America ${ }^{3}$. The Brazilian Program for STD/AIDS aims at prevention through free access to condoms, treatment, support from civil society, and a variety of approaches targeting vulnerablepopulations $s^{4}$. Brazilian prevention efforts targeting high-risk populations have achieved some impressive success, particularly among injection-drug users and commercial sex workers ${ }^{5}$. An egalitarian approach to pre venting and treating HIV infection, health-advocacy organizations with groups working among homosexuals, commercial sex workers, and injection-drug users receive government funding for their activities. ${ }^{5}$. But what does this mean at a local level where peer-educators in these fields carry out prevention?

This evaluative research project was conducted in various prostitution quarters and zones visited by three peer-education projects on STD/ HIV/AIDS in northern Brazil6. The objective of the initial project was "to reduce morbidity and mortality due to STD/AIDS and their impact by blocking the transmission of STDs (including AIDS) between sex workers and their clients" (in 1998, 350 sex workers were identified in this city of 80,000 inhabitants). The project sought to improve citizenship rights and to encourage safer sexual practices as well as to provide specialized medical and nursing care for free diagnosis and treatment of STDs. Based on a peer-education method, five community peer-educators were initially selected, employed and trained to carry out educational activities about systematic condom use ${ }^{7}$. These activities were conducted in different meeting places (port, bars, hotels, public parks, streets, schools, etc.). They received ongoing training in STD/HIV/AIDS prevention and in various issues related to human and citizenship rights. In 2002, the value of theinterventions was verified by mean sof epidemiological studies and sexual behavior questionnaires ${ }^{7,8}$. In 2004, two other peer-conducted prevention projects emerged from this initial sex workers project, one with men who have sexual relations with men (M SRM ) and another with adolescents in peripheral neighborhoods.

\section{Aims: knowledge production and participatory research context}

M any studies with peer education suggest the need to enhance self-respect and self-autonomy. Sensitization, critical consciousness and empowerment of peers can be a first step in the mobilization of collective action with regard to a HIV/ AIDS problem ${ }^{9-13}$. However, there are limitations to community participation without significant changes at the institutional level ${ }^{9}$, development of theory and measurement of empowerment in HIV/AIDS prevention and without transformations in public health research and practice ${ }^{11}$. To facilitate partici pation, the role of the researcher or health professional must range from being an expert who enters a community for intervention purposes to skills such as community organizing, group facilitation, conflict resolution, public speaking or advocacy ${ }^{11}$.

The problem of danger in enhancing participation in HIV/AIDS peer-education

Despite the growing importance of participation and critical consciousness in peer education with HIV/AIDS programs, no study underlines the dangers involved in conducting peer-education, evaluation and research when living in the community. None of the 26 case studies and additional resources in the Toolkit for targeted HIV/ AIDS prevention and care in sex work settings ${ }^{14}$ deals with the potential physical and psychological danger for health promoters, professionals, nurses or peer-educators. International and national "tool-kit" procedures limit HIV /AIDS programming and evaluation to the production of information that can be submitted to inter-site comparisons. Local information is often lacking or discarded as anecdotal. This is especially the casein HIV/AIDS projects with sex workers, prisoners or other marginalized populations. Community and public health nurses arein a position 
to experienceuncomfortable details - such as violence, drug trafficking, prostitution and sociopolitical restraints- that higher-level agencies prefer to ignore. These experiences are often left out of final reports at the cost of glossing over the real data production emerging from forefront professionals.

In this light, this paper tries to provide a critical study of HIV/AIDS peer education in its socio-political context. It also stresses the particular contribution of a nurse's field experience to selfevaluation with peer-education projects traversed by dangerous local issues and unpredictability. A participatory/ethnographic approach sought to take into account the meaning and values for the various actors concerned in their milieu. The author's prior nursing practice and living experience inside the community had oriented the research strategy. She collaborated in the implementation of theinitial sex workers' project in the community, where she had been living and working as a community health nurse from 1994 to 2000. It was during this period that she developed her concern with an evaluation that would reveal the real conditions of conducting peer education at a local level. Shealso recognized the costsfor participants and personnel of delving into the concrete conditions where information could be obtained. Because of their proximity with participants and AIDS prevention field activities, nurses are in a position to bring together the shared experiences of different individuals affected by the actions of peer-education projects. This study suggests that nurses havea roleto play in the conceptualization of evaluation at a local level in public health programs. It also underlines thethreats to their physical and social safety, which they might share with peer-educators.

\section{Research questions}

- How can the full participation of the main actors lead to the production of knowledge, which is both synthetic and grounded in its context of production?

- How should the evaluation take into account thelocal conditions that ground the information gathered in its context of production which, because it is tainted by unpredictability and dangerousness, cannot but influencetheunderstanding of the research aims?

\section{Proximity to local actors}

An analysis from previous nursing experiences in the field identified a variety of potential stakeholders involved with prostitution and marginalized areas. The various actors were: (a) direct local actors (users, peer-educators, the social activity structure of prostitution areas clients, bar owners, etc.); (b) indirect local actors (socio-sanitary network; health, administrative and service professionals, political and legal apparatuses, public administration, police, military, cultural apparatuses: representatives of the community in general, religious sects); and (c) regional and national actors (reference centers, politicians, research community). The author was living 0.5 $\mathrm{km}$ from the major prostitution areas. Actors not considered during the project's planning phase played an important role in the intervention and its evaluation (drug traffickers, street gangs, illegal organizations related to the target population in prostitution zones). The research was also conducted during a pre-election campaign period, which was not without effect in the local community. The strategy can be summed up as participatory action research ${ }^{15-17}$, and evaluation from the actors' perspective ${ }^{18-20}$, with an ethnographic dimension that considers the socio-cultural and socio-political dimensions of the context in which the research took place.

\section{Research strategy}

for an evaluation at the for efront

The evaluation principally gathered qualitative evidence at three peer-education projects (sex workers; men who havesexual relations with men (MSRM ); and adolescents in peripheral neighborhoods). Thefieldwork, which consisted in living in the community for fivemonths, was made up of: 23 intensive participant observation sessions of four major prostitution zones (day and night time) and two prisons (female and male); regular visits to project sites, clinics, sex workers and peer-educators' family home, municipal health services and community organizations; 21 individual, semi-structured interviews (1 STD/ AIDS regional actor, 2 politicians, 3 user-volunteers, 10 users-sex workers, 2 project coordinators, 3 peer-educators) and 18 collective, semistructured interviews ( 3 weekly Sharing Group of Appreciations [SGA] made up of 5, 7 and 6 peer educators during 3 months). The semistructured interviews were based on the Evalua- 
tion Guide for Community Organizations ${ }^{21}$. Intentional and snowball sampling and recruitment were organized via an operational plan elaborated in the field according to opportunities and actor availability. This tool was adapted to Brazilian and Amazonian language and culture in the light of suggestions made by local members and conceptions of Latin American popular education ${ }^{17}$. Open thematic questionnaires were used to begin discussions with participants. The collective and individual interviews were aimed at gaining an understanding of: (a) the perception the participants have of their role in the organization; (b) the relationship each participant has with the other categories of actors; (c) their evaluation/perception of the activity or action being discussed; and (d) their recommendations for improvement.

In addition, documentary analysis of project documents, national health network websiteand local newspapers were helpful tools in developing a socio-political understanding of the research field. A self-ethnographic journal served as an aid for self-reflection about the cultural significations and consciousness of inevitable ethnocentric perceptions. M anual coding by metaphor was used to derive emergent and convergent themes, categories and constructs ${ }^{22}$. For the Sharing Groups of Appreciations, the data were transcribed in a form similar to the minutes of a Community-based AIDS organization (CBAO) meeting. These were collectively validated and analyzed by deliberation and negotiation with participants, who were invited to remove the information elements that they felt would pose a threat if divulged. The researcher explicitly excluded the kind of information, which might be kept secret by often violent methods in this area. The research protocol was approved by the Health Sciences Research Ethics Board at the University of M ontreal (Canada) and by the Ethics Committee of the Fundação Alfredo-da-M atta (M anaus, Brazil).

Findings: a multiplicity of actors with convergent and divergent perspectives

The variety of research techniques and actors studied led to a variety of informational and attitudinal data. In order to present them succinct$l y$, the findings are organized in terms of their convergences and divergences, placing the peereducators as the pivotal actors. Few quotations translated from Portuguese to English are pre- sented. The results are presented in a way to emphasize the collective analysis with participants. This data reduction has the obvious cost of oversimplification, and stresses generalizations that a fuller research report analyzed in much greater detail ${ }^{6}$.

\section{Converging perspectives}

Personal values and identity

What emerges from the collective evaluation groups is the importance peer-educators assign to personal values and identification, largely with regard to the MSRM project. Peer-educators present themselves mainly through human values vis-à-visthetarget population and their peers, which influences the practices in their communities (cordiality, peace, growth, courage, hope, selfgiving). They present themselves individually through the "project's goal," the "encounter" with the target population, the 'project's officeand the work areas," and the "educational brochure they produced" (from peer-educators SGA). Other peer-educators perceive the "courage" it takes to walk the streets, to give presentations, to approach clients in bars or to be both a health professional and a homosexual (from peer-educators SGA). The regional STD/AIDS actor and one collaborator from public administration concur in evaluating theinterveners' success as being related to their contribution to prevention activities that respect their clients' values. Although they have no formal recognition in the structure of the projects, some participants acknowledge their particular role as "user-volunteers" (from individual users).

Living in precarious living conditions, theinterviewed volunteersfeel that their collaboration is in terms of "who they are" and their "lives" (from individual users-volunteers). The meaning they give to their volunteer actions is characterized principally by a desire to "help themselves" and to help their peers in developing mutual aid and communication networks. One volunteer said that his role was as a "transvestite multipli$\mathrm{er}^{\prime}$ in rural areas (from individual user-volunteer). He was driven by a desire to help, support and even enhancethe peer-education project, but in a way that was in line with his particular lifestyle. This first convergence is al so built around the perceptions of the peer-educators in the peereducation process. M ore than half of the multipliers came directly form the population target- 
ed by the projects. Although they had not necessarily completed high school, most of them were working towards this end. The participants attended training sessions on approaches to use STD/HIV/AIDS and prevention in bars and prostitution zones. To translate actions into acts, the participants learned for the most part by observing their moreexperienced colleaguesin thezones that were visited - e.g. attitudes, behavior with clients, sex workers and bar owners (from peereducators SGA). A part from some visits supervised by the coordinators, there was no strict monitoring of the prevention activities.

\section{Sense of comradeship}

Whilethesense of human belonging and participating is a dominant feature of their ties to the prevention program, another equally important element is thesense of comradeship they develop in working together. It is "by questioning others who have more experience" that "working together" becomes a priority (from peer-educators SGA). It makes it possible to share knowledge and experiences with a view to dealing with the complex and unforeseen situations that arise in the field. M any of their comments illustrate the collective nature of this work and demonstrate that in the participants' view, it is not the "work" of a single person: Everyone works together; we don't work alone. In this way, everyone expresses their ideas and teaches something to the others. The project relies on peer education, so there are two or three of us together [who make up a team]. With regard to discrimination, we have to go together to 'confront' people, to offer education activities in schools, and to present slides. (from one peer-educator SGA).

Working together is unanimously cited as the means for dealing with the dangerousness of the field: It's important to be very familiar with the work sectors: in the park, at the port, in the neighborhood. The work is dangerous: there are many rival street gangs in the neighborhoods. We have to carry condoms with us; they are 'passes' between two territories and enable us to enter neighborhoods at night. (from one peer-educators SGA)

It is generally left up to the peer-educators to develop strategies for dealing with the various challenges they face in their work settings. Although they do not feel involved in formal decision-making, some of the user-volunteers stress the possibility of transmitting their project's mission and orientation by peers. Onevolunteer feels that he is collaborating not as "trabalhista" [ paid worker], but by giving work-related advice to the peer-educators (from individual user-volunteer). The majority of the interviewed sex workers feel that they are "participants" in the project. In their view, "participating means continuing to be involved in the project, to come here on a regular basis" (from individual sex worker). Several of them seetheir roleas being essential to the project: "the project lives through us" (from individual sex worker).

\section{Collective history and trajectory changes}

A third point of convergence is a perception, widely shared by both peer-educators and users, that the prevention project is both a recovery of their collective history and evidence of ongoing changes that hold out the hope of continued improvement of their situation. M oreover they feel that this improvement is due to their efforts and sacrifices. At onepoint during collectiveinterviews, a peer-educator said that he had discovered that the projects' evaluation was something like" writing our history" (from one peer-educators SGA). They also developed an increased awareness of support networks and the change in social relations among them and with their surroundings. $M$ any peer-educators recognize that their projects provide them with ben efits; especially those who have themsel ves experienced changes in their individual social trajectory (e.g. getting a formal job and a position in the formal health network). Some of them speak in terms of a process of changing personal pathways, characterized largely by "shifting from one state to another", moving from the role of user to user/volunteer to that of an official peer-educator (from individual peereducator).

They considered the possi bility of going from an illicit job to a socially recognized formal job as a health educator (peer educator). "I used to be marginalized and viewed as a "bicha" [travesty], like an animal. With this job, I am now viewed as a human being" (from individual peer-educator). The life stories related to the project converge around "a life change" via greater involvement in the community (from individual peer-educator). The stories follow a logic that generally begins with them leaving their environment because of discrimination at home, at school or in their community. Following the introduction of the STD/ HIV/AIDS awareness and prevention activities into their city, the majority of all research participants noticed a decrease in discrimination against homosexuals and sex workers. One pol- 
itician noted the project's contribution in helping homosexuals to find work. "These people used to belaughed at; now they can work, can speak in public, and can be esteemed" (from individual public administrator). Hecited the case of a homosexual peer-educator who was applauded by adolescents following an educational presentation about STD/HIV/AIDS in their school: "In this way, people earn respect" (from individual public administrator).

\section{Diverging perspectives}

\section{Organizational levels}

The convergences observed among participants should not hide the divergences among them, which appear most explicitly at theprojects' organizational levels. The viewpoint of peer-educators, whileperson- and project-centered, tends to differ from the accepted program. Responsible for maintaining a regular and ongoing presence in peer-education activities, they can be viewed in their dual capacity as peer and intervener. They consider themselves active members of the organization and not only paid workers (who come largely from target populations). During the self-evaluation process, these participants began to discuss the fact that all three peerconducted prevention projects had "common concerns" (from peer-educators SGA). For example, one group noted that there "are several young adolescents and minors who are sex workers and/or homosexuals" (from one peer-educators SGA). Both the observations and the collective interviews underlined the fact that the most natural collective way of doing things among peereducators is opposed to the way things are prescribed by STD/HIV/AIDS program planners. The latter propose projects that are administratively "separate," have "specific activities," and are intended for a "homogeneous target population", whereas peer-educators interviewed perceive prevention projects as global activities aimed at all aspects of their community involvement for its betterment (from individual local coordinator).

A majority of peer-educators view themselves as producers of the peer-conducted prevention projects experience. They feel that they areableto judge and eventually alter their actions on the basis of knowledge they acquire in the course of their practice. During self-evaluation activities, they characterize themselves as "the voices of the collective evolution and history of the projects" (from peer-educators SGA). It is mainly the peereducators who are the pivotal interveners or intermediaries between the local context and the universal goals of a STD/HIV/AIDS prevention project. Peer-educators situate themselves "between the community and the public health agencies" (from peer-educators SGA). They have to give an account of their activities to health authorities. This suggests that their interventions actual izetwo cultures within a single space- that of the organizational reality of a public health institution and that of a community organization (this role of "mediator" in between institution and peers is largely described by two French sociologists 23,24 ). They easily identify what they are expected to emphasize and what is best left in the background of shared information. It was only by developing privileged ties of trust (both through professional services and interpersonal trust) that the nurse's research could enrich information collection with formal and personal viewpoints.

Perception of the social change

into preventive actions

Peer-educators from one group noted that they were not "robots distributing condoms" (from one peer-educators SGA). Participatory observation in their field work, houses, social activities and formal meetings reveals that they generate social changes in their community through direct contact with the target populations (sex workers, homosexuals, adolescents in poor neighborhoods, street gangs, etc.). For example, they create a new network of relationships in these populations. While all the uservolunteers wereinterested in STD/HIV/AIDSinformation, they were mostly drawn to volunteer work by social activities and events piloted by homosexuals.

For physicians, prevention and medical consultation are a response. For their part, users place more importance on "changing interpersonal relations" and the "network" (from individual users). In their self-evaluation of prevention projects, users, user-volunteers and peereducators rallied around the collective effort toward a global improvement of health conditions and of all their determinants ${ }^{10,25,26}$. Peer-educators meet the target populations in their highrisk communities. By negotiating with the police chief, bar owners and health professionals, peereducators even become "advocates," enabling sex workers and transvestites to obtain the right to 
otherwise inaccessible health services. Intervention practices go beyond theinstrumental dimension of STD/HIV/AIDS prevention. For peer-educators, prevention is a "pathway for the creation of a new network" and for the acknowledgement of a space within the formal work setting (from peer-educators SGA).

\section{Refusal of silencing "the anecdotal"}

A second area of divergence is the rejection of the organizational temptation to reduce observational data to what is explicitly targeted in the original research plan, which includes the working conditions of participants and researchers. In the case of nurses working as practitioners and who have important ties with the participants, this reductive characterization is insufficient. It is impossi bleto obtain valid information without digging it out in life contexts, which are too often marked by the actors' concrete living conditions, which include misery, illegality, violence, and criminality (author's self-ethnographic journal). This context is shared by thenurse practitioner who, like the people she works with, shares an understanding of the situation, which goes far beyond the limits of the pre established research objectives.

Getting close to peopleimmersed in these settings entails more than description, understanding and proximity. It also includes living in their world-a world fraught with danger to them and to their contacts (author's self-ethnographic journal). The author worked in conditions where information-factual, relational or criminal-is dangerous, even when acquired fortuitously. "Local" is more than a standpoint for understanding. It is also an accepted recognition of the conflicts and the dangers, which become part and parcel of the intervention and research process for both the practitioner and thepeopleshecomes into contact with.

Conclusion: self-evaluation by local actors as an HIV/AIDS strategy

By linking ethnographic insertion to in-depth individual and collectiveinterviews with local actors, this study has provided a distinctiveevidential base, which plumbs the "lived experience" of basic STD/HIV/AIDS peer-educatorsin their unpredictablecontext. It brings out two dimensions that need to be considered in the evaluation of HIV prevention: their evolution over time and their socio-cultural and socio-political context. It is also important to pay attention to project evolution over time during the evaluation process. The contact with reality draws out forms of inertia, oppositions and distortions which were previously unsuspected, products of the unplanned community involvements and the risks these entailed ${ }^{27}$. Thefeeling of danger when walking through prostitution zones at night was shared both by peer-educators and the researcher during her field visits with them. To be immersed in the activities helps to understand the fact that "deviations" or "gaps" from the initial HIV prevention objectives might actually be adjustments and safeguards. The area in which this study took place included drug traffickers, owners of bars in which prostitutes ply their trade, street gangs and local political elements with whom the peer-educators (including theauthor) had to consult, in addition to negotiating with "visibleand recognized" peersin theofficial health system ${ }^{28}$. Policies, programs and actions should focus more on socially established relationships, interdependence and changeableidentities ${ }^{26}$.

This research project drew out the importance of the role played by nurses in AIDS care within the framework of evaluative research focused on HIV prevention among highly vulnerablepopulations, particularly in a fluid social context characterized by instability, precariousness, unpredictability and dangerousness. Because they are close to the prevention site, nurses can facilitatethe public expression of practicesinvented by peer-educators and thereby encourage the emergence of "new knowledge forms" in the prevention of STD/HIV/AIDS. N urses can contribute by: (a) encouraging ways of expression of local marginalized peer-educators or users of a preventive program; (b) trying to understand the dynamics and conditions of local work and implication in peer-education; (c) building solutions with locals during a participatory evaluation; and (d) enhancing evaluation theory by being involved with a network of international colleagues (e.g. an actual growing Latin American network interested in the evaluation of health policy and social change). By virtue of the epistemological hegemony of the scientific order and the behaviorist models developed by international agencies and AIDS research centers in the U.S. and Europe, models which incorporate social dimensions often go against the grai ${ }^{25}$. In this sense, nurses have to step outside of a narrowly defined medical role and embrace a broader community-action oriented health promotion role. 


\section{Acknowledgments}

The foundations of the present discussion reside in ongoing theoretical work and community evaluation with Ricardo Zúñiga. Theauthor wishes to thank Dr. Adele Schwartz Benzaken for inviting her to return to Brazil so that she could elaborate her research project, for accompanying the author in her fieldwork, and for the quality of her expertise in the area of STD/HIV/AIDS prevention among sex workers. The translation was founded by the program Analyse et Évaluation des Interventions en santé (AnÉis), University of M ontreal.

\section{References}

1. Pedersen M. Political violence, ethnic conflict, and contemporary wars: broad implications for health and social well-being. Soc Sci M ed 2002; 55:173-190.

2. Farmer P. Pathologies of Power. Health, Human rights, and the new war on the poor. Berkeley: University of California Press; 2003.

3. UNAIDS. AIDS epidemic update: special report on HIV prevention. Geneva: Joint UN Programme on HIV/AIDS and the WHO; 2005.

4. Brazilian Program for STD/AIDS. Response M agazine + 2005: experiences of the Brazilian AIDS Programme. Brasília: Ministry of Health; 2005.

5. Okie S. Fighting HIV - Lessons from Brazil. N Eng J Med 2006; 354 (19):1977-1981.

6. Laperrière $H$. L'évaluation de l'action préventive en contexte d'imprévisibilité. Les enjeux d'un projet de prévention des MTS/VIH/Sida par les pairs, Amazonas, Brésil [dissertation]. M ontréal $(\mathrm{Q} C)$ : Université de Montréal, Faculté des sciences infirmières; 2004.

7. Benzaken AS, Garcia EG, Sardinha JCG, Pedrosa $V L$, Loblein O. Risk perception for STD and behaviour changes in sex professionals of $M$ anacapuru municipality. J Bras de DST 2003; 15(2):9-14.

8. Benzaken AS, Garcia EG, Lourenço VP, Sardinha JCG, Loblein O. Baixa prevalencia de DST en profesionales del sexo en un municipio del interior de Amazonas. J Bras de DST 2002; 14(4):9-19.

9. Asthana S, Oostvogels R. Community participation in HIV prevention: Problems and prospects for community based strategies among female sex workers in Madras. Soc Sci M ed 1996; 43(2):133-148.

10. Parker R. Empowerment, community mobilization and social change in the face of HIV/AIDS. AIDS 1996; 10(Supp 3):S27-S31.

11. Beeker C, Guenther-Gray C, Raj A. Community Empowerment Paradigm Drift and the Primary Prevention of HIV/AIDS. Soc Sci M ed 1998; 46:831-842.

12. Busza J, Schunter B. From Competition to Community: Participatory Learning and Action among Young Debt Bonded Vietnamese Sex Workers in Cambodia. Reprod Health Matters 2001; 9(17):72-81.

13. Campbell C, MacPhail C. Peer education, gender and the development of critical consciousness: participatory HIV prevention by South African youth. Soc Sci M ed 2002; 55:331-345.
14. WHO. Toolkit for Targeted HIV Prevention and Care in Sex Work Settings. 2005. [accessed 2006 Jul 2]. Available from: http://www.who.int/hiv/toolkit/sw

15. Fals-Borda, O. The application of participatory action-research in Latin America. Inter Soc 1987; 2(4):329-347.

16. Reason P. Human inquiry in action. Newbury Park: Sage; 1995.

17. Brandão CR. Pesquisa participante. São Paulo: Brasiliense; 1985.

18. Guba EG, Lincoln YS. Fourth generation evaluation. Newbury Park: Sage; 1989.

19. House ER, Howe KR. Values in evaluation and social research. Thousand Oaks: Sage; 1999.

20. Zúñiga R. L'évaluation dans l'action sociale. Autonomies et solidarités. [accessed 2006 Jul 20]. Available from: http://homepage.mac.com/ricardo. b.zuniga

21. Jalbert $Y$, Pinault L, Renaud G, Zúñiga R. A SelfEvaluation Guide for Community Organizations. M ontréal: COCQ-sida; 1997.

22. Miles MB, Huberman AM. Qualitative Data Analysis ( $\left(2^{\text {nd }} \mathrm{ed}.\right)$. Thousand Oaks: Sage; 1994.

23. Dubet F. Le déclin de l'institution. Paris: du Seuil; 2002.

24. Latour B. Changer de société. Refaire de la sociologie. Paris: La Découverte; 2006.

25. Parker R, Camargo K. Pobreza e HIV/AIDS: aspectos antropológicos e sociológicos. Cad Saúde Pública 2000; 16 (Supl 1):89-102.

26. Ayres JRCM. Educational practices and the prevention of HIV/Aids: lessons learned and current challenges. Interface 2002; 6(11):11-24.

27. Vasconcelos EM. Educação Popular e Pesquisa-Ação como Instrumentos de Reorientação da Prática M édica. In: Gonsalves EP, organizador. Educação e Grupos Populares: temas (re) correntes. Campinas: Alinea Editora; 2002: 99-116.

28. Laperrière $H$, Zúñiga R. Sociopolitical determinants of an AIDS prevention program: multiple actors and vertical relationships of control and influence. PPNP 2006; 7(2):125-135.

Artigo apresentado em 17/10/2006

Aprovado em 25/06/2006

Versão final apresentada em 30/07/2007 